\title{
The use of integrative therapy based on Yoga and Ayurveda in the treatment of a high-risk case of COVID-19/SARS-CoV-2 with multiple comorbidities: a case report
}

\author{
Alka Mishra' ${ }^{1}$ S Sumitra A. Bentur ${ }^{2}$, Sonika Thakral ${ }^{3,4^{*}} \mathbb{C}$, Rahul Garg $^{4,6,7}$ and Bhanu Duggal ${ }^{5}$
}

\begin{abstract}
Background: We report a high-risk case of a coronavirus disease 19 (COVID-19)-positive patient with comorbidities including diabetes mellitus (DM), hypertension (HTN), hypothyroidism and chronic kidney disease (CKD), treated successfully using an integrative therapy plan based on Ayurveda and Yoga, along with government-mandated compulsory modern western medicine (MWM) treatment. Recently, some evidence has been emerging on the use of Ayurveda for treatment of COVID-19. The classical texts of Ayurvedic medicine such as Charaka Samhita and Sushruta Samhita contain descriptions of pandemics of similar proportions and describe them as Janapadoddhvansa, meaning the destruction of communities, along with their causes and treatment.
\end{abstract}

Case presentation: The case reported herein is a 55-year-old man from Delhi, India, with confirmed (tested) COVID19, who first took MWM for 7 days before seeking integrative therapy. The patient has comorbidities including DM, HTN, hypothyroidism and CKD and had developed symptoms including fever (which was resolved by the time integrative therapy was started), sore throat, dry cough, body aches, weakness, bad taste and smell, and heaviness in the abdomen. Based on the patient's symptoms and comorbidities, a treatment plan including Ayurvedic medicines, Yoga protocol, dietary recommendations and lifestyle modifications was prescribed by a registered Ayurveda doctor and a Yoga consultant. The patient started experiencing improvement in all the symptoms within 2 days after starting the treatment; he reported approximately $75 \%$ relief from the symptoms after 5 days, and almost complete relief within 9 days. Also, the blood sugar levels (both fasting blood sugar [FBS] and postprandial blood sugar [PPBS]) exhibited significant improvement after 5 days, and decreased to within the normal range within 12 days. Besides relief in symptoms, the patient's real-time reverse transcription polymerase chain reaction (RT-PCR) test done on the 19th day returned negative results.

Conclusions: Integrative therapy was found to be effective in mitigating the symptoms of COVID-19 in this patient with multiple comorbidities. Moreover, a significant improvement in blood sugar levels (not under control with modern medicine) was also achieved. Integrative therapy based on the classical texts of Ayurveda and Yoga may offer a promising and scalable treatment option for COVID-19 patients. A case series or a suitably designed randomized controlled trial is needed to assess its efficacy.

Keywords: COVID-19, Ayurveda, Yoga, Integrative therapy, Case report

\footnotetext{
${ }^{*}$ Correspondence: sthakral@iitd.ac.in

${ }^{4}$ National Resource Center for Value Education in Engineering, Indian Institute of Technology, Delhi, India

Full list of author information is available at the end of the article
}

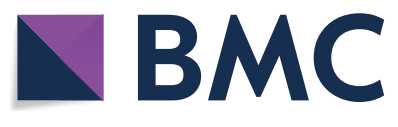

(c) The Author(s) 2021. Open Access This article is licensed under a Creative Commons Attribution 4.0 International License, which permits use, sharing, adaptation, distribution and reproduction in any medium or format, as long as you give appropriate credit to the original author(s) and the source, provide a link to the Creative Commons licence, and indicate if changes were made. The images or other third party material in this article are included in the article's Creative Commons licence, unless indicated otherwise in a credit line to the material. If material is not included in the article's Creative Commons licence and your intended use is not permitted by statutory regulation or exceeds the permitted use, you will need to obtain permission directly from the copyright holder. To view a copy of this licence, visit http://creativecommons.org/licenses/by/4.0/. The Creative Commons Public Domain Dedication waiver (http://creativeco mmons.org/publicdomain/zero/1.0/) applies to the data made available in this article, unless otherwise stated in a credit line to the data. 


\section{Introduction}

The coronavirus disease 2019 (COVID-19) pandemic has wreaked havoc on every aspect of human life on planet Earth. As on August 28, 2020, more than 24.4 million cases of COVID-19 have been reported in more than 227 countries and territories, resulting in more than 831,827 deaths [1]. Although there are several clinical trials underway, no cure has yet been found for COVID-19 in modern western medicine (MWM).

The presence of comorbidities such as diabetes mellitus (DM), hypertension (HTN), chronic obstructive pulmonary disease (COPD) or old age leads to poorer clinical outcomes in COVID-19 patients [2-5], and presents additional challenges in the management of the illness. Physical inactivity, high-fat diet and uncontrolled HTN in addition to superposed infection are strong risk factors for cardiovascular complications such as myocardial toxicity in COVID-19 [6, 7]. The mortality rate for hospitalized COVID-19 patients in China has been reported as $3.1 \%$ [2], while among these hospitalized patients, for those who have one or more of the nine comorbidities (DM, HTN, COPD, cardiovascular disease, cerebrovascular disease, hepatitis B infection, malignancy, chronic kidney disease [CKD], immunodeficiency), the mortality rate has been reported as $8.8 \%$ [2]. In the same cohort, the percentage of patients for whom the illness progresses to a severe stage has been reported at $16 \%$, whereas for patients with comorbidities, the corresponding percentage is substantially higher, at $32.8 \%$. Although the precise figures may vary with geography, the fact that the presence of comorbidities leads to poor clinical outcomes in COVID-19 patients has been independently confirmed in many studies from various countries $[3,4,8,9]$.

Ayurveda is a system of traditional Indian medicine which is based on sound therapeutic principles and has a proven history of empirical use $[10,11]$. It is one of the world's oldest holistic healing systems. According to the Ayurvedic system of medicine, a healthy person should have a stable equilibrium (congenial homeostasis) of Doshas (Vata, Pitta, Kapha-psycho-biological rhythms), Agni (metabolism/digestion), Dhatu (body tissues/elements that provide them nourishment) and Mala (excreta), and the well-being of senses, mind and soul [10]. Every individual has a unique combination of these constituent elements, which is known as the individual's Prakruti or unique mind-body constitution (Ashtanga Hridaya, Sharira Sthana, Chapter 3, Verse 83) [12]. When an imbalance occurs in this equilibrium, it causes disease, and the Ayurvedic system of medicine seeks to remove this imbalance, to regain a healthy state $[10,11]$.

The occurrence of disease can be further understood as follows: the abovementioned constituent elements have a propensity to change, influenced by various factors such as the environment we live in, change in seasons, the food that is consumed, negative experiences, presence of physical toxins, irritants, microorganism or impurities, unhealthy habits and emotions. These influences distort the natural balance of these elements in an individual, increase ama (toxins), contributing to vikruti (vitiation of the constituent elements); this imbalance manifests as a lack of energy, excess mucous, inflammation, and a wide variety of dysfunction and diseases $[10,11,13]$. By using the Ayurvedic principles, the unique Prakruti (constitution) of the individual is assessed, the vikruti (vitiation) that has occurred is diagnosed and a personalized treatment plan is advised accordingly. Thus, the Ayurveda system of medicine is inherently personalized, which treats the patient by considering the individual constitution (Prakruti) as well as the causes of the symptoms (vikruti).

Classical Ayurveda texts such as Charaka Samhita (Vimana Sthana, Chapter 3) [11] and Sushruta Samhita (Sutra Sthana, Chapter 6, Verses 19, 20) [10] contain descriptions of pandemics and describe them as Janapadoddhvansa-Jana-pada (meaning community) + Udhvansa (meaning destruction), literally translating to "destruction of communities." These texts offer specific guidelines with regard to the treatment of diseases that affect people during Janapadoddhvansa.

Yoga is yet another ancient wisdom from India, which is an extremely deep science that helps one lead a harmonious life [14]. The classical text Yoga Vasishta [15] (Book 6, Chapter 81) describes a healthy person as one who is free from physical disease as well as from erroneous affections of the mind. Yoga deals with the holistic principle of body-mind-soul, which proclaims that a human being can experience five dimensions of gross and subtle existence, called Pancha kosha, or five sheaths, namely Annamaya (physical body), Pranamaya (energy field), Manomaya (mental dimension), Vijnanamaya (related to intuitive knowledge) and Anandamaya (level of bliss) kosha (Taittiriya Upanishad) $[16,17]$. Prana (the vital life force that is responsible for all the gross and subtle activities) pervades all five sheaths, and nourishes and sustains them [17]. Yogic practices are aimed at achieving the proper distribution and circulation of Prana within the gross and subtle realms of existence, for holistic well-being.

Ayurveda also describes the concept of Panchaprana or Pancha Vayu (five manifestations of the vital life force in the human body) (Ashtanga Hridaya, Sutra Sthan, Chapter 12, Verse 4) [12]. Panchaprana govern different areas of the body and different physical, neurological and mental activities. When they are functioning harmoniously, they promote the health and vitality of the body and mind, and elevate one spiritually. 
Thus, both Ayurveda and Yoga are powerful sciences that are aimed at the proper modulation of Prana in the human being, and when administered together in an integrative manner, these can be extremely effective with regard to restoring health, as well as managing or curing diseases.

In this paper we report presumably the first high-risk case of COVID-19 (with reference to the studies available in peer-reviewed open literature), treated successfully using integrative therapy comprising Ayurveda and Yoga. Although there have been some case reports (see the section on Related Works) and theoretical works on the use of Ayurveda or Yoga for COVID-19, the authors are not aware of any published work reporting the successful treatment of high-risk cases of COVID-19 through Ayurveda or Yoga. The present case offers sufficiently supportive evidence that an integrative therapy plan based on Yoga and Ayurveda can be useful in treating even highrisk cases of COVID-19 with mild to moderate symptoms. With regard to the work ahead, a suitably designed case series or randomized controlled trial (RCT) would be advisable to further establish its efficacy for high-risk COVID-19 patients.

\section{Related works}

There is emerging evidence that Ayurvedic treatment methodologies and herbal medicines may be effective in combating COVID-19. Girijaa and Sivan [18] describe one of the first case reports of a patient with COVID-19 treated entirely with Ayurveda. In a study using molecular dynamics simulations, Kumar et al. [19] report that withaferin $\mathrm{A}$ (Wi-A) and withanone (Wi-N), derived from a common Ayurvedic herb called Ashwagandha, may block the entry of the severe acute respiratory syndrome coronavirus 2 (SARS-CoV-2) into cells. Several herbs including Tulsi (Ocimum sanctum) and Haldi (Curcuma longa-turmeric) used as Ayurvedic medicines are well known for their immunomodulatory properties [20-24]. Ayurvedic treatment has also been found to be effective in other COVID-like illnesses such as influenza [25-27] and chikungunya [28]. Several studies have been conducted to understand the COVID-19 pandemic and the conditions that it causes from the perspective of Ayurveda [29-35]. Based on these observations and the study of classical Ayurveda texts, several experts have proposed the use of Ayurveda for both prophylactic [36-49] and therapeutic purposes [34, 38-41, 43, 44, 50$58]$ in COVID-19. Some studies have also suggested that lifestyle modifications, such as immunity-boosting food, can aid in fighting the current situation [59]. Many studies have come up with suggestions for reforms in policies enabling the adoption of Ayurveda in the treatment plan for COVID-19 patients [42, 60-62]. The Government of
India, Ministry of AYUSH, has issued an advisory comprising Ayurveda-based immunity-boosting measures for self-care during the COVID-19 crisis [63], and an advisory for the general public on the use of Ayurveda (and other traditional systems of medicine) as a preventive measure for COVID-19 as well as for managing the symptoms of COVID-19 [64]. The same department also issued guidelines for Ayurveda practitioners [65] and Yoga practitioners [66] for treating COVID-19 patients. Several ongoing clinical trials are evaluating the efficacy of Ayurveda-based interventions for both prophylactic and therapeutic use in patients with mild to moderate COVID-19 symptoms.

Traditional Chinese medicine (TCM), which is based on principles similar to those of Ayurveda, has been used extensively in China for treating COVID-19. The Chinese government has actively promoted the use of TCM for management of COVID-19. As a result, several studies have been published on the use of TCM for COVID-19 [67-70]. The Chinese doctors now recommend the use of TCM along with western medicine in treating COVID-19 [71, 72]. According to Yang et al. [73], more than $85 \%$ of the cases in China have received TCM-based treatment. Several RCTs on TCM are presently in different stages of completion. Most of the reviews on RCTs on the efficacy of TCM for COVID-19 [74-78] report positive findings (see $[79,80]$ for reviews on the mechanism of action of TCM). Several countries have issued guidelines for the use of traditional medicine for COVID-19. See [81, 82] for a review of such guidelines.

Despite the above studies on TCM, caution has also been advised in the use of TCM for COVID-19. For example, Gray and Belessis [83] state that the use of TCM may cause "more harm than good." Cyranoski [84] argues that TCM is still an unproven treatment and is being excessively promoted by certain governments. A review by Pang et al. [85] reported that after a comprehensive literature search, they found 26 published clinical controlled trials of TCM for COVID-19, among which 11 were RCTs with 1301 patients, but none of the RCTs were placebo-controlled or double-blinded. There was significant variation in the types of patients, interventions and outcomes in different RCTs. Also, for most of the published trials, the protocols had not been registered before case recruitment. Thus, based on the above observations, it may be concluded that TCM may offer a promising option for treating COVID-19, yet suitably designed multi-country RCTs may be needed to assess its efficacy.

In light of the above observations, the present integrative therapy plan was designed, which comprises elements of Yoga and Ayurveda, along with dietary recommendations and lifestyle modifications, as a treatment 
option for COVID-19. It was hypothesized that integrative therapy based on Ayurveda and Yoga would be effective in treating COVID-19 patients.

\section{Case presentation}

\section{Patient information}

A Delhi-based 55-year-old man (confirmed positive) COVID-19 patient (height: 5'3"; weight: approximately $70 \mathrm{~kg}$ ) completed the online registration and consent forms on July 1, 2020, to receive Yoga and Ayurvedabased integrative therapy via telemedicine. The Ayurveda doctor and the Yoga consultant talked to the patient over the phone the same day to take his medical history and symptoms pertaining to COVID-19, and to prescribe integrative therapy-based treatment. The patient reported that his oxygen saturation value ranged between 95\% and 98\% (never required oxygen supplementation) and his blood pressure was under control (with medication).

\section{History of the present illness}

The patient was asymptomatic 3 weeks prior to the first consultation for the integrative therapy. Later, he started developing symptoms of pneumonia, after which he went to a hospital and underwent the RT-PCR test. The patient was found to be positive on June 24, 2020. Subsequently, he was prescribed the following allopathic medications for 10 days: nitazoxanide $500 \mathrm{mg}$, doxycycline $100 \mathrm{mg}$, pantoprazole $40 \mathrm{mg}$, vitamin $\mathrm{C}$, multivitamin (methylcobalamin, pyridoxine and folic acid) and levocetirizine $5 \mathrm{mg}$. On July 1, 2020, at the time of the first consultation for the integrative therapy, the patient was quarantined at home (although the doctors had advised hospitalization).

\section{Complaints due to present illness}

Resolved prior to the first consultation The patient had fever for about 10 days until June 22, 2020, after which he never had fever again. He also reported having had a dry cough and body aches earlier, both of which no longer persisted at the time of his first consultation.

Existing at the time of the first consultation The patient reported experiencing occasional obstruction in the throat while speaking for a substantial duration of time. $\mathrm{He}$ also felt weak and sounded very low and lacking in energy. According to the patient's description, he experienced exhaustion even in doing his own daily chores. The patient had heaviness in the abdomen (gastric upset) and often experienced a bloated feeling. Also, the patient had been having a sense of bad smell and taste, which occurred less frequently then as compared to earlier. The patient's appetite was reduced.

\section{Other existing illnesses/comorbidities}

The patient was found to have the following comorbidities at the time of the first consultation. He had type $2 \mathrm{DM}$ for the past 10 years and had been on allopathic medication (glimepiride $2 \mathrm{mg}$, vildagliptin 50 $\mathrm{mg}$, voglibose $0.3 \mathrm{mg}$ ) for the same. However, despite regular use of the prescribed medicine, the illness was not very well controlled, with fasting blood sugar (FBS) mostly remaining above $200 \mathrm{mg} / \mathrm{dl}$ and postprandial blood sugar (PPBS) above $250 \mathrm{mg} / \mathrm{dl}$, as well as renal dysfunction (as evident in his reports dated June 23, 2020). The patient was also found to be hypertensive for the past 20 years, and had been on allopathic medication (Torcilin-10); HTN was under control with the medication. He had hypothyroidism for 22 years which was being treated with allopathic medication (levothyroxine sodium $75 \mathrm{mcg}$ ) and was under control.

\section{Family and social history}

The patient had a family history of HTN in the father, grandfather and paternal uncle. There was no family history of DM. The patient had no history of smoking or taking alcohol.

Since the patient was advised through telemedicine, physical examination was not possible.

\section{Occupational details}

The patient is a self-employed businessman.

\section{History of past illnesses}

The patient had undergone cholecystectomy (removal of gall bladder) 20 years earlier.

\section{Data from diagnostic tests}

The data from hematology, biochemistry and ultrasound reports is as follows. The parameters marked with an asterisk (*) have values outside the reference range.

The hematology report of the patient, dated June 22, 2020, gave the following information:

- Complete blood count (white blood cell count $6.54 \times 10^{3} / \mu \mathrm{l}$; neutrophil percent $68.5 \%$; lymphocyte percent $20.8 \%$; monocyte percent" $9.1 \%$; eosinophil percent" $0.8 \%$; basophil percent $0.2 \%$; neutrophil number $4.48 \times 10^{3} / \mu \mathrm{l}$; lymphocyte number $1.36 \times 10^{3} / \mu \mathrm{l}$; monocyte number $0.6 \times 10^{3} /$ $\mu \mathrm{l}$; red blood cell count $5.34 \times 10^{3} / \mu \mathrm{l}$; hemoglobin concentration* $11.4 \mathrm{~g} / \mathrm{dl}$; hematocrit" $34.6 \%$; mean corpuscular volume* $64.8 \mathrm{fL}$; mean corpuscular 
hemoglobin* 21.3pg; mean corpuscular hemoglobin concentration $32.9 \mathrm{~g} / \mathrm{dl}$; red cell distribution width* $17.9 \%$; platelet count ${ }^{*} 50 \times 10^{3} / \mu \mathrm{l}$; mean platelet volume 10.3fl; procalcitonin* $0.051 \%$; platelet distribution width*14\%-Remarks: hypochromia, microcytosis).

- Erythrocyte sedimentation rate* $22 \mathrm{~mm}$ first hour.

The biochemistry report dated June 22, 2020, gave the following information:

- Glycosylated hemoglobin (HbA1c)* (high-performance liquid chromatography on D10 analyzer) 9.2\% - Remarks: Average blood glucose concentration is around $210-220 \mathrm{mg} / \mathrm{dl}$.

- Renal profile (blood urine nitrogen-kinetic ultraviolet test* $30.4 \mathrm{mg} / \mathrm{dl}$; creatinine-kinetic color test* $1.83 \mathrm{mg} / \mathrm{dl}$; uric acid-enzyme color test* $10.68 \mathrm{mg} /$ dl; sodium* $132 \mathrm{mEq} / \mathrm{l}$; potassium* $5.31 \mathrm{mEq} / \mathrm{l}$; calcium-color test $9.4 \mathrm{mg} / \mathrm{dl}$; inorganic phosphorusUV test $3.0 \mathrm{mg} / \mathrm{dl}$-Remarks: deranged kidney function, electrolyte imbalance).

The ultrasound (whole abdomen) report, dated June 23, 2020, mentioned:

- Grade II hepatic steatosis, hepatosplenomegaly, umbilical hernia.

\section{Ayurvedic interpretation of the patient's condition Diagnosis}

Based on the above history and discussion with the Ayurvedic doctor and Yoga consultant, the diagnosis of the patient's illness included COVID-19, with type 2 DM, HTN, hypothyroidism and CKD. Except for the inability to perform a physical examination, no known diagnostic challenges were encountered.

\section{Pathophysiology}

According to Ayurvedic principles, because jwara (fever), shvasa (respiratory distress) and kasa (cough) are the three major symptoms of this roga (disease), the roga marga (pathway of disease) of this roga can be considered to be Abhyantara (internal origin) [18]. Because there is respiratory distress, along with other symptoms, there is Pranavaha Sroto Dushti (obstruction of the Pranavaha Srotas, that is, the subtle micro-channels in the body that are the pathways for the vital life force); also, one of the primary seats of this disease is Uras (chest region) [18]. Based on these observations, this disease can be characterized as Agantuja Sannipataja Jwara, wherein Vata-Kapha doshas are primarily vitiated [18].

In Agantuja Sannipataja Jwara, Agantuja implies Agantu (external), which is caused by Bhoota Abhishanga (external causative factors like a virus); this in turn causes the vitiation of all three Doshas, that is Vata, Pitta and Kapha [18]. Because of the vitiation of all three Doshas, the term Sannipataja is used [18]. As per Ayurvedic principles, the treatment of such a Jwara is similar to that of Nija Jwara, that is, one caused by vitiation of Doshas [18].

\section{Etiology}

According to Ayurvedic principles, this disease can be correlated with Agantuja Sannipataja Jwara, wherein Vata-Kapha are primarily vitiated [18]. Furthermore, this is an extremely contagious disease, caused by Bhoota Abhishanga (external causative factors like virus), that is characterized in Ayurvedic texts as a Janapadoddhvansa disease [10, 11, 18]. Classical Ayurvedic texts like Charaka Samhita (Vimana Sthana-Chapter 3) [11] and Sushruta Samhita (Sutra Sthana, Chapter 6, Verses 19, 20) [10] contain descriptions of similar pandemics, and describe them as Janapadoddhvansa-Janapada, meaning community + Uddhvansa, meaning destructionliterally translating to destruction of communities. The symptoms of illness during Janapadoddhvansa, as mentioned in classical texts, include cough, dyspnea, asthma, vomiting, nasal catarrh (common cold), headache and fever [10]. These texts also offer specific guidelines with regard to the treatment of diseases that affect people during Janapadoddhvansa, which include Ayurvedic medicines and spiritual practices $[10,11]$.

\section{Therapeutic intervention}

This section presents the detailed treatment plan as well as the details of the subsequent compliance of the patient.

\section{Treatment plan}

The treatment plan comprised (1) Ayurvedic medicines, includingGiloy Ghanvati, Ashwagandha vati, Pathyadi Kwath (pravahi) and Diabecon; (2) Yoga protocol, consisting of Sukshma Vyayama, breathing exercises, Asanas, Shavasana, Pranayama and Dhyana; (3) dietary modifications such as Usha Paan, intake of fruits and green vegetables, and avoiding cold or heavy to digest food; and (4) lifestyle modifications such as adoption of spiritual practices.

The detailed prescription of Ayurvedic medicines including the dosage, specific details about each component of the Yoga protocol, and dietary and lifestyle modifications suggested, are given below. 
Table 1 Composition of Ayurvedic medicines

\begin{tabular}{ll}
\hline Common name & Botanical name \\
\hline Giloy Ghanvati & \\
Giloy & Tinospora cordifolia \\
Ashwagandha vati & \\
Ashwagandha & Withania somnifera \\
Pathyadi Kwath (pravahi) [119] & \\
Harad & Terminalia chebula \\
Baheda & Terminalia bellerica \\
Amla & Emblica officinalis \\
Neem chhal & Azadirachta indica \\
Giloy & Tinospora cordifolia \\
Haldi & Curcuma longa \\
Diabecon [120] & \\
Shilajeet & Asphaltum punjabianum \\
Meshashringi/Gudmara/Madhunashini & Gymnema sylvestre \\
Peetashala/Vijaysar/Indian Kino Tree & Pterocarpus marsupium \\
Turmeric & \\
Haldi & Curcuma longa \\
\hline
\end{tabular}

The following Ayurvedic medicines were prescribed: Giloy Ghanvati (three doses of two tablets each to be taken after meals with lukewarm water), Ashwagandha vati (two doses of two tablets each to be taken after meals), Pathyadi Kwath (pravahi) (15 ml mixed with an equal quantity of lukewarm water to be consumed twice a day 30 minutes after meals), and Diabecon (two doses of one tablet each to be taken 30 minutes before meals) (composition given in Table 1).

The Yoga protocol designed for the patient included Sukshma Vyayama (subtle joint movements for upper and lower body parts), breathing exercises (four exercises with five iterations in each), Asanas (Parshva Sukhasana, Sukhasana twist, Utthana Mandukasana, Ardha Ushtrasana, Meru Vakrasana, Ardha Halasana-with one leg folded, Anantasana, Pawan Muktasana), Shavasana, Pranayama (sectional breathing and full yogic breathing, Anulom-Vilom, Bhramari, Udgeet), and Dhyana (mindful breathing). Online guided sessions were given for the first 14 days, after which a recorded video of the protocol (with verbal instructions and demonstration) was provided for the patient to practice independently. Looking at the anxiety level of the patient, he was also advised to practice Yoga Nidra [86] (guided yogic sleep and relaxation practice), for which he was provided a link to guided audio instructions (in Hindi) by Swami Satyananda Saraswati; the duration of the session was 42 minutes.

The following dietary and lifestyle modifications were also recommended to the patient: beginning the day with Usha paan, that is, drinking 2-3 glasses of lukewarm water, dietary intake of green vegetables, fruits, sprouts,
Table 2 Compliance chart

\begin{tabular}{|c|c|c|c|c|c|}
\hline \multirow[t]{3}{*}{ Day } & \multicolumn{5}{|c|}{ Intervention } \\
\hline & Giloy & Ashwagandha & Pathyadi & Diabecon & Yoga+ \\
\hline & Ghanvati & Vati & Kadha & & Pranayama \\
\hline 1 & $\checkmark$ & $\checkmark$ & $\checkmark$ & $\checkmark$ & $\checkmark$ \\
\hline 2 & $\checkmark$ & $\checkmark$ & $\checkmark$ & $\checkmark$ & $\checkmark$ \\
\hline 3 & $\checkmark$ & $\checkmark$ & $\checkmark$ & $\checkmark$ & $\checkmark$ \\
\hline 4 & $\checkmark$ & $\checkmark$ & $\checkmark$ & $\checkmark$ & $\checkmark$ \\
\hline 5 & $\checkmark$ & $\checkmark$ & $\checkmark$ & $\checkmark$ & $\checkmark$ \\
\hline 6 & $\checkmark$ & $\checkmark$ & $\checkmark$ & $\checkmark$ & $\checkmark$ \\
\hline 7 & $\checkmark$ & $\checkmark$ & $\checkmark$ & $\checkmark$ & $\checkmark$ \\
\hline 8 & $\checkmark$ & $\checkmark$ & $\checkmark$ & $\checkmark$ & $\checkmark$ \\
\hline 9 & $\checkmark$ & $\checkmark$ & $\checkmark$ & $\checkmark$ & $\checkmark$ \\
\hline 10 & $\checkmark$ & $\checkmark$ & $\checkmark$ & $\checkmark$ & $\checkmark$ \\
\hline 11 & $\checkmark$ & $\checkmark$ & $\checkmark$ & $\checkmark$ & $\checkmark$ \\
\hline 12 & $\checkmark$ & $\checkmark$ & $\checkmark$ & $\checkmark$ & $\checkmark$ \\
\hline 13 & $\checkmark$ & $\checkmark$ & $\checkmark$ & $\checkmark$ & $x$ \\
\hline 14 & $\checkmark$ & $\checkmark$ & $\checkmark$ & $\checkmark$ & $\checkmark$ \\
\hline 15 & $\checkmark$ & $\checkmark$ & $\checkmark$ & $\checkmark$ & $\checkmark$ \\
\hline 16 & $\checkmark$ & $\checkmark$ & $\checkmark$ & $\checkmark$ & $\checkmark$ \\
\hline 17 & $\checkmark$ & $\checkmark$ & $\checkmark$ & $\checkmark$ & $x$ \\
\hline 18 & $\checkmark$ & $\checkmark$ & $\checkmark$ & $\checkmark$ & $\checkmark$ \\
\hline 19 & $\checkmark$ & $\checkmark$ & $\checkmark$ & $\checkmark$ & $\checkmark$ \\
\hline 20 & $\checkmark$ & $\checkmark$ & $\checkmark$ & $\checkmark$ & $\checkmark$ \\
\hline 21 & $\checkmark$ & $\checkmark$ & $\checkmark$ & $\checkmark$ & $\checkmark$ \\
\hline
\end{tabular}

barley, ragi flour, wheat porridge, sahajan (drumstick), roasted gram, methi (fenugreek), turmeric milk and dry fruits. Also, he was advised to refrain from cold, sour, fried, spicy or other food items that are heavy to digest; these included food items like curd, cold drinks, ice creams, chilled water, any refrigerated food items, black gram pulse (or any food item prepared with black gram), jackfruit and so on. Besides the above dietary recommendations, the patient was encouraged to undertake spiritual practices such as meditation and chanting at his convenience, for which he was provided a link to the suggested spiritual practices [87].

A detailed justification of the proposed treatment plan is provided in Additional file 1.

\section{Compliance}

The compliance details for the patient are given in Table 2.

\section{Results}

The first consultation with the patient was on July 1 , 2020. He was under home isolation during the entire course of treatment. He started observing improvement 
Table 3 Progress of the patient and evolution of the treatment plan

\begin{tabular}{|c|c|c|c|c|c|}
\hline Day & Date & $\mathrm{FBS}(\mathrm{mg} / \mathrm{dl})$ & PPBS (mg/dl) & RBS (mg/dl) & Follow-up details \\
\hline 0 & $1 / 7 / 2020$ & - & - & - & $\begin{array}{l}\text { Generally the blood sugar values were } \mathrm{FBS}>200 \mathrm{mg} / \mathrm{dl}, \mathrm{PPBS}>250 \mathrm{mg} / \mathrm{dl} \text { while the } \\
\text { patient was taking allopathic medication for the same; PPBS was reported to be } 230 \\
\mathrm{mg} / \mathrm{dl} \text { on 30/6/2020 }\end{array}$ \\
\hline 1 & $2 / 7 / 2020$ & 192 & - & - & $\begin{array}{l}\text { Symptoms reported/observed: difficulty in speech, weakness, sometimes feeling of bad } \\
\text { smell and taste, heaviness in abdomen (due to gas formation), uneasiness in body, } \\
\text { less appetite }\end{array}$ \\
\hline 2 & $3 / 7 / 2020$ & 169 & - & - & $\begin{array}{l}\text { Improvement observed; approximately } 25 \% \text { relief reported in all symptoms; lightness in } \\
\text { the body reported }\end{array}$ \\
\hline 3 & $4 / 7 / 2020$ & 190 & 206 & - & Doing Yoga (twice daily); feeling good, with improvement in all symptoms \\
\hline 4 & $5 / 7 / 2020$ & 160 & 206 & - & Approximately $50 \%$ relief reported in all symptoms; lightness in the body reported \\
\hline 5 & $6 / 7 / 2020$ & 155 & 175 & - & $\begin{array}{l}\text { No weakness; normal appetite; taste and smell almost normal; approximately 75\% relief } \\
\text { reported. Second RT-PCR done }\end{array}$ \\
\hline 6 & $7 / 7 / 2020$ & 140 & - & 110 & $\begin{array}{l}\text { No sore throat; no weakness; normal taste and smell; almost no other problem except } \\
\text { mild heaviness in abdomen; approximately } 80 \% \text { relief reported }\end{array}$ \\
\hline 7 & $8 / 7 / 2020$ & 140 & - & 110 & No problem except mild heaviness in abdomen \\
\hline 8 & $9 / 7 / 2020$ & 130 & 230 & - & $\begin{array}{l}\text { Second RT-PCR report received on 8/07/2020 was positive; slight change made in the } \\
\text { prescription: (i) Diabecon } 1 \text { tablet in the morning and } 2 \text { tablets in the evening (previ- } \\
\text { ously } 1 \text { tablet in the evening); (ii) advised to take (ajwain }+ \text { saunf }+ \text { dhaniya) powder } \\
\text { ( } 1 / 2 \text { spoon) with lukewarm water after meals }\end{array}$ \\
\hline 9 & $10 / 7 / 2020$ & 110 & 150 & - & Improvement in all problems (including heaviness in abdomen) \\
\hline 10 & $11 / 7 / 2020$ & 110 & 150 & - & $\begin{array}{l}\text { No problem except mild heaviness in abdomen; dose of Diabecon changed to } 2 \text { tablets } \\
\text { twice daily (patient advised to start the revised dose from 12/7/2020) }\end{array}$ \\
\hline 11 & $12 / 7 / 2020$ & 130 & 140 & - & No problem except mild heaviness in abdomen; started Diabecon 2 tablets twice daily \\
\hline 12 & $13 / 7 / 2020$ & 99 & 112 & - & No problem except mild heaviness in abdomen. Third RT-PCR done \\
\hline 13 & $14 / 7 / 2020$ & 108 & 112 & - & No problem except mild heaviness in abdomen \\
\hline 14 & $15 / 7 / 2020$ & 120 & 165 & - & No problem except mild heaviness in abdomen \\
\hline 15 & $16 / 7 / 2020$ & 108 & 140 & - & $\begin{array}{l}\text { RT-PCR test inconclusive as per the report; no problem except mild heaviness in abdo- } \\
\text { men }\end{array}$ \\
\hline 16 & $17 / 7 / 2020$ & 90 & 140 & - & No problem except mild heaviness in abdomen \\
\hline 17 & $18 / 7 / 2020$ & & & & No problem except mild heaviness in abdomen \\
\hline 18 & $19 / 7 / 2020$ & & & & No problem except mild heaviness in abdomen \\
\hline 19 & $20 / 7 / 2020$ & & & & $\begin{array}{l}\text { Sample given for RT-PCR test; the patient's allopathic doctor reduced the dosage of his } \\
\text { diabetes medication, that is glimepiride changed from } 2 \mathrm{mg} \text { to } 1 \mathrm{mg} \text {; no problem } \\
\text { except mild heaviness in abdomen }\end{array}$ \\
\hline 20 & $21 / 7 / 2020$ & & & & $\begin{array}{l}\text { Diabecon changed to Diabecon DS } 1 \text { tablet twice daily; no problem except mild heavi- } \\
\text { ness in abdomen }\end{array}$ \\
\hline 21 & $22 / 7 / 2020$ & & & & RT-PCR negative; no problem except mild heaviness in abdomen \\
\hline
\end{tabular}

FBS fasting blood sugar, PPBS postprandial blood sugar, RBS random blood sugar, RT-PCR real-time reverse transcription polymerase chain reaction

in symptoms 2 days after the beginning of the treatment. The second RT-PCR was done on July 6 , and was positive. A slight modification was made in the intervention on July 9, as reported in Table 3. By the ninth day after starting the treatment, all the symptoms reported by the patient were resolved, except mild heaviness in the abdomen. The third RT-PCR done on July 14 was inconclusive, and another test was done on July 20, which was negative. Moreover, the patient's uncontrolled blood sugar level showed significant improvement, with FBS of $90 \mathrm{mg} / \mathrm{dl}$ and PPBS of 140 $\mathrm{mg} / \mathrm{dl}$. Most importantly, the patient was in a much better state of mind (as evident in his feedback during consultations) and sounded much more confident by the end of the treatment.

\section{Timeline of COVID-19 symptoms and treatment}

A detailed description of the progress made by the patient and the medicines given during the course of the treatment is given in Table 3.

\section{Follow-up}

Follow-up was carried out until August 01, 2020. The patient continued to report mild heaviness in the abdomen until July 26, 2020. Thereafter, beginning July 27, 
Table 4 Follow-up details

\begin{tabular}{|c|c|c|c|}
\hline & June 23, 2020 & August 14, 2020 & Reference range \\
\hline \multicolumn{4}{|l|}{ Blood sugar } \\
\hline Glycosylated Hb (HbA1c) & $9.2 \%$ & $6.6 \%$ & $<6.5 \%$ \\
\hline \multicolumn{4}{|l|}{ Renal profile } \\
\hline $\begin{array}{l}\text { Blood urea nitrogen-kinetic ultraviolet (UV) test (urease, } \\
\text { glutamate dehydrogenase) }\end{array}$ & $30.4 \mathrm{mg} / \mathrm{dl}$ & $11.2 \mathrm{mg} / \mathrm{dl}$ & $7.94-20.09 \mathrm{mg} / \mathrm{dl}$ \\
\hline Creatinine-kinetic color test & $1.83 \mathrm{mg} / \mathrm{dl}$ & $0.75 \mathrm{mg} / \mathrm{dl}$ & $0.67-1.17 \mathrm{mg} / \mathrm{dl}$ \\
\hline
\end{tabular}

2020, he reported complete relief and rejuvenation. Besides the symptoms that appeared after infection with the coronavirus, it was observed that the other ailments which the patient had a history of were also positively impacted. Table 4 summarizes the improvements observed in the reports of the patient received on August 14,2020 , as compared to those received on June 23, 2020; significant improvement can be seen in the hemoglobin A1c (HbA1c) values and renal profile parameters. In a more recent follow-up taken on October 23, 2020, the patient reported that he has continued to take the prescribed integrative therapy and is feeling complete relief of all his symptoms, including those related to his comorbidities. He further reported that, after looking at his present condition and most recent diagnostic test results, which indicated normal values for $\mathrm{HbA1c}$, renal and lipid profile, his consulting physician further reduced his dosage of MWM for DM and HTN.

\section{Discussion}

This study reports the successful treatment of a high-risk case of COVID-19 in a patient with several comorbidities, using an integrative therapy plan based on Yoga and Ayurveda, along with government-mandated modern western medicine treatment. Various unique aspects of this treatment approach are discussed below.

Since the patient's fever was already controlled before enrollment in the integrative therapy, it is possible that he may have been in the convalescent phase at the time of enrollment. It must be noted that the Ayurveda system of medicine does not treat a disease condition in isolation; it treats a patient holistically for overall health while strengthening the body's innate mechanisms involved in the restoration of health. The patient had uncontrolled blood sugar levels (which is known to adversely impact the immune system [88]) for the past 10 years despite MWM treatment. The rapid reduction in the blood sugar levels after the initiation of integrative therapy may have contributed to a rapid recovery from the other symptoms and provided a faster path to the patient's overall wellbeing. Besides the data presented in Table 4, according to a more recent follow-up taken on October 23, 2020, the patient has continued to use the prescribed integrative therapy as an adjunct to his MWM treatment for DM and reported HbA1c within normal limits. His MWM dose for DM has been further reduced by his consulting physician.

Besides the variety and severity of physiological symptoms posed by COVID-19, it deeply affects patients psychologically as well $[89,90]$. Owing to the highly contagious nature of the coronavirus, the social stigma associated with the disease and the mandated isolation period have a deep adverse impact on the already nervous patients [91]. This stress and anxiety may tend to further weaken the already compromised immune system, thereby potentially creating a vicious cycle. The patient treated in the present case was undergoing a similar situation at the time of the first consultation. With his symptoms prevailing for a long period, and two more of his family members being infected (one of them being hospitalized), the patient was in severe distress and exhibited anxiety. The integrative therapy administered to him not only helped manage his physiological symptoms, but also helped control his anxiety and stress (see for example $[92,93]$ for reviews on Yoga for anxiety). Within a week, an observable change in his confidence level was seen, and he appeared much more calm and peaceful. This change may be attributed to his regularity in attending the Yoga sessions, in addition to the relief experienced as his COVID-19 symptoms subsided. The authors believe that apart from boosting immunity, Yoga and Pranayama practices contributed immensely to his overall healing by inducing a relaxation response [94] in the body.

Promising results observed in several research studies suggest a favorable impact of Yoga on immune function, stress response, mental health and quality of life [95-100]. The usefulness of nasal irrigation, a yogic practice, in improving the symptoms and health status of patients with sinonasal disease has also been observed [101]. A key symptom associated with COVID-19 is the onset of dyspnea between the fourth and tenth days of illness [102]. Studies suggest that COVID-19 patients with hypoxia or dyspnea may have a higher risk of mortality or developing severe symptoms [103, 104]. It has been 
reported that a simple intervention such as prone positioning improves clinical outcomes in such cases [105, 106]. Yoga and Pranayama have been found helpful in cases of high-altitude hypoxia [107] and several similar interventions in pulmonary rehabilitation for patients with acute respiratory distress syndrome (ARDS)/COPD [108-114]. Owing to its role in stress reduction and immune modulation, Yoga has been proposed as a complementary therapy in the management of infectious conditions like COVID-19 [115]. Bushell et al. [116] suggest Yoga practices and meditation as a potential adjunctive treatment for COVID-19. In light of the above observations, and looking at the results of the present study, it is hypothesized that the integrative therapy plan, which comprises elements of Yoga and Ayurveda, along with dietary recommendations and lifestyle modifications, would be effective in treating COVID-19 patients, either as an adjunct to MWM or as a stand-alone treatment. A case series involving a larger number of high-risk patients or a suitably designed RCT is needed to systematically assess its efficacy.

\section{Conclusion}

The success of the integrative therapy in this high-risk case of COVID-19 is evident in that the patient not only recovered from the symptoms, but a sense of overall wellbeing was bestowed on him.

This successfully treated case certainly calls for more well-designed studies on the proposed integrative therapy approach, possibly leading to its adoption in the standard treatment provided to COVID-19 patients.

\section{Patient's perspective on the treatment}

After recovery from symptoms and a negative RT-PCR report, a subjective feedback was taken from the patient to understand his perspective on the intervention. The patient expressed immense satisfaction and a sense of confidence. He was amazed and delighted to find that besides aiding in a speedy recovery from the symptoms of COVID-19, including weakness, anxiety and depression, Yoga and Ayurveda had managed to control his blood sugar level as well. The normal sugar levels observed by the end of the treatment were astounding given that regular allopathic medication could not achieve this. The patient was so convinced about the efficacy of Yoga and Ayurveda that he suggested his spouse (who was also tested positive for COVID-19 and had been pursuing only allopathic medication) seek Ayurvedic consultation. Most importantly, he is determined to adopt Yoga in his lifestyle.

\section{Supplementary Information}

The online version contains supplementary material available at https://doi. org/10.1186/s13256-020-02624-1.

Additional file 1: Justification for the prescribed treatment.

\section{Abbreviations}

SARS-CoV-2: Severe acute respiratory syndrome coronavirus 2; DM: Diabetes mellitus; HTN: Hypertension; CKD: Chronic kidney disease; FBS: Fasting blood sugar; PPBS: Postprandial blood sugar; RT-PCR: Real-time reverse transcription polymerase chain reaction; COPD: Chronic obstructive pulmonary disease; ARDS: Acute respiratory distress syndrome; TCM: Traditional Chinese medicine; RCT: Randomized controlled trial; QRT: Quick relaxation technique; DRT: Deep relaxation technique.

\section{Acknowledgements}

The authors would like to express sincere gratitude to Dr. Saurabh Mishra, Dev Sanskriti Vishwavidyalaya, for his continued guidance and valuable suggestions. The authors benefited immensely from his all-around expertise. The authors also acknowledge the help and support extended by Prof. Bharat Bajirao Bhoyar, Chaudhary Brahma Prakash Ayurved Charak Sansthan.

\section{Authors' contributions}

AM is an Ayurveda doctor and a Yoga consultant and was responsible for Ayurveda treatment of the patient and writing the corresponding sections of the manuscript. SAB is also an Ayurveda doctor and a Yoga consultant. She was responsible for designing and delivering the Yoga intervention to the patient and writing the corresponding parts of the manuscript. ST was responsible for patient coordination, setting up the telemedicine infrastructure and data management. She was also involved in the routine follow-up (including compliance and tracking of the symptoms), and writing some sections of the manuscript. RG was responsible for conceptualization of the project, overall coordination of the team and writing parts of the manuscript. BD shared her insights about the disease from the perspective of allopathic medicine. All authors read and approved the final manuscript.

\section{Funding}

No funding was received for the reported case study.

Availability of data and materials

All necessary data are available (in de-identified form) from the corresponding author on reasonable request.

\section{Ethics approval and consent to participate}

This study did not require explicit ethics approval as the case was treated following the Telemedicine Practice Guidelines for Ayurveda, Siddha and Unani Practitioners (issued by the Central Council of Indian Medicine) [117] and the notification from the Ministry of AYUSH for undertaking research on COVID 19 through Ayurveda, Unani, Siddha and Homeopathy systems [118]. Informed consent for participation was duly obtained from the subject prior to commencement of the treatment.

\section{Consent for publication}

Written informed consent was obtained from the patient for publication of this case report and any accompanying images. A copy of the written consent is available for review by the Editor-in-Chief of this journal.

\section{Competing interests}

The authors declare that they have no competing interests.

\section{Author details}

${ }^{1}$ Department of Ayurveda and Holistic Health, Dev Sanskriti Vishwavidyalaya, Haridwar, India. ${ }^{2}$ Ayurveda physician and yoga expert, Noida, India. ${ }^{3}$ Shaheed Sukhdev College of Business Studies, University of Delhi, Delhi, India. ${ }^{4}$ National Resource Center for Value Education in Engineering, Indian Institute of Technology, Delhi, India. ${ }^{5}$ Department of Cardiology, All India Institute of Medical Sciences, Rishikesh, India. ${ }^{6}$ Amar Nath and Shashi Khosla School of Information Technology, Indian Institute of Technology, Delhi, India. 
${ }^{7}$ Department of Computer Science and Engineering, Indian Institute of Technology, Delhi, India.

Received: 17 September 2020 Accepted: 9 December 2020 Published online: 24 February 2021

\section{References}

1. Wikipedia: COVID-19 pandemic by country and territory. Retrieved August 28, 2020 from https://en.wikipedia.org/wiki/COVID-19_pande mic_by_country_and_territory.

2. Guan W-J, Liang W-H, Zhao Y, Liang H-R, Chen Z-S, Li Y-M, Liu X-Q, Chen R-C, Tang C-L, Wang T, et al. Comorbidity and its impact on 1590 patients with Covid-19 in China: a nationwide analysis. Eur Respir J. 2020;55(5):2000547

3. Wang B, Li R, Lu Z, Huang Y. Does comorbidity increase the risk of patients with COVID-19: evidence from meta-analysis. Aging. 2020;12(7):6049.

4. Singh AK, Gupta R, Misra A. Comorbidities in COVID-19: Outcomes in hypertensive cohort and controversies with renin angiotensin system blockers. Diabetes Metab Syndr Clin Res Rev. 2020;14:283-7.

5. Zhu L, She Z-G, Cheng X, Qin J-J, Zhang X-J, Cai J, Lei F, Wang H, Xie J, Wang W, et al. Association of blood glucose control and outcomes in patients with COVID-19 and pre-existing type 2 Diabetes. Cell Metab. 2020;31:1068-1077.e3.

6. Sook LW, Sablihan N, Ismail S, Devarai N, Mooi CS. Factors associated with the level of physical activities among non-academic staffs in the faculty of medicine and health sciences of a public university in Selangor, Malaysia. Mal J Med Health Sci. 2019;15(2):47-55.

7. Devaraj NK. Prevalence, factors influencing, and knowledge about adherence to lipid-lowering therapy among hyperlipidemia patients. Int J Cardiol. 2017;249:7-8.

8. Espinosa OA, Zanetti ADS, Antunes EF, Longhi FG, Matos TAd, Battaglini PF. Prevalence of comorbidities in patients and mortality cases affected by SARS-CoV2: a systematic review and meta-analysis. Revista do Instituto de Medicina Tropical de São Paulo. 2020;62:e43.

9. Franki R. Comorbidities increase COVID-19 deaths by factor of 12. Medscape. Retrieved August 12, 2020 from https://www.medscape.com/ viewarticle/932486, 2020.

10. Murthy KRS. Susruta Samhita. Varanasi: Chaukhambha Orientalia; 2008.

11. Sharma PV. Caraka Samhita. Varanasi: Chaukhambha Orientalia; 2008.

12. Vidyanath R. Illustrated Astanga Hrdaya. Chaukhambha Sanskrit Pratishthan, 4360, 4, Ansari Rd, Daryaganj, New Delhi, India, 2018.

13. Singhal GD. Madhava-Nidana. Chaukhamba Sanskrit Pratishthan, 4360, 4, Ansari Rd, Daryaganj, New Delhi, India, 2016.

14. United Nations: Resolution adopted by the General Assembly on 11 December 2014. 69/131. International Day of Yoga. Retrieved August 20, 2020 from https://en.wikisource.org/wiki/Page:United_Nations_ Resolution_No._69-13_Internationa_Day_of_Yoga).djvu/1. 9 Jan 2015.

15. Arya RP. The Yoga Vasistha of Valmiki. Chaukhamba Sanskrit Pratishthan, 4360, 4, Ansari Rd, Daryaganj, New Delhi, India, 2005.

16. Sharvananda S. Taittiriya-Upanishad. Mylapore: The Ramakrishna Math; 1921.

17. Saraswati SN. Prana and Pranayama. Yoga Publications Trust, Munger, Bihar, India. 2009.

18. Girija P, Sivan N. Ayurvedic treatment of COVID-19/SARS-CoV-2: a case report. J Ayurveda Integrat Med. 2020. https://doi.org/10.1016/j. jaim.2020.06.001.

19. Kumar V, Dhanjal JK, Bhargava P, Kaul A, Wang J, Zhang H, Kaul SC, Wadhwa R, Sundar D. Withanone and Withaferin-A are predicted to interact with transmembrane protease serine 2 (TMPRSS2) and block entry of SARS-CoV-2 into cells. J Biomol Struct Dyn. 2020. https://doi. org/10.1080/07391102.2020.1775704.

20. Mondal S, Varma S, Bamola VD, Naik SN, Mirdha BR, Padhi MM, Mehta N, Mahapatra SC. Double-blinded randomized controlled trial for immunomodulatory effects of Tulsi (Ocimum sanctum Linn.) leaf extract on healthy volunteers. J Ethnopharmacol. 2011;136(3):452-6.

21. Jamshidi N, Cohen MM. The clinical efficacy and safety of tulsi in humans: a systematic review of the literature. Evid Based Complement Alternat Med. 2017;2017:9217567.
22. Gudi SK, Ramesh TB, Kumar P. Tulsi" - the Wonder Herb (Pharmacological Activities of Ocimum Sanctum). Am J Ethnomed. 2014;1:89-95.

23. Rathaur P, Raja W, Ramteke P, John SA. Turmeric: the golden spice of life. Int J Pharm Sci Res. 2012;3(8):1987.

24. Jagetia GC, Aggarwal BB. "Spicing Up" of the immune system by curcumin. J Clin Immunol. 2007;27(1):19-35.

25. Shubhashree M, Naik R, Doddamani S, et al. Preventive strategies to combat infections-a review of traditional practices and Ayurveda concepts. Int J Complement Alternate Med. 2020;13(3):125-9.

26. Sharma P, Sharma VB. Understanding of swine flu through Ayurveda. J Ayurveda Holistic Med. 2015;3(2):30-2.

27. Kalamkar GS, Sawai R, Rampurkar M. Role of Ayurveda in communicable diseases. Int J Ayurvedic Med. 2015;6(1):28-31.

28. Central Council for Research in Ayurveda and Siddha, Department of AYUSH, Ministry of Health and Family Welfare, Government of India: Management of Chikungunya Through Ayurveda and Siddha: a Technical report. Retrieved August 11, 2020 from http://www.ccras.nic.in/sites /default/files/22092016_MANAGEMENT\%200F\%20CHIKUNGUNYA\%20 THROUGH\%20AYURVEDA\%20AND\%20 SIDDHA-\%20TECHNICAL\%20 REPORT.pdf. 2009.

29. Puthiyedath R, Kataria S, Payyappallimana U, Mangalath P, Nampoothiri V, Sharma P, Singh MK, Kumar K, Trehan N. Ayurvedic clinical profile of COVID-19-A preliminary report. J Ayurveda Integrat Med. 2020. https:// doi.org/10.1016/j.jaim.2020.05.011.

30. Kirthana V, Venkataiah B, Murthy MN, et al. COVID 19 in ayurvedic perspective. In J Health Allied Sci. 2020;9(5):91.

31. Nesari TM, et al. Ayurveda: the promising shelter for the mankind in the wake of COVID-19 pandemic. J Ayurveda Case Rep. 2020;3(1):1.

32. Garg G. COVID-19 pandemic: the ayurvedic perspective. Int J Ayurveda Tradit Med. 2020;2(2):1-2.

33. Prarthana H, Kokatnur SS, Desai S. Understanding of COVID-19 disease through Ayurveda. J Ayurveda Integrat Med Sci. 2020;5(2):169-74.

34. Stella BP, Kokatnur SS, Desai S. Understanding of COVID-19 in Ayurveda and its managing view. J Ayurveda Integrat Med Sci. 2020;5(2):161-5.

35. Meshram KR, et al. Critical review on COVID-19 in perspective of Ayurveda and its legal \& psychological backgrounds. Int J Res Anal Rev. 2020;7(2):424-35.

36. Tillu G, Chaturvedi S, Chopra A, Patwardhan B. Public health approach of Ayurveda and Yoga for COVID-19 prophylaxis. J Alternat Complement Med. 2020;26(5):360-4.

37. Rajkumar RP. Ayurveda and COVID-19: Where psychoneuroimmunology and the meaning response meet. Brain Behav Immun. 2020;87:8-9.

38. Patwardhan B, Chavan-Gautam P, Gautam M, Tillu G, Chopra A, Gairola S, Jadhav S. Ayurveda rasayana in prophylaxis of COVID-19. Curr Sci. 2020;118:1158-60.

39. Goothy SSK, Goothy S, Choudhary A, Potey G, Chakraborty H, Kumar $\mathrm{AH}$, Mahadik V. Ayurveda's holistic lifestyle approach for the management of Coronavirus disease (COVID-19): possible role of tulsi. Int J Res Pharm Sci. 2020;11(SPL1):16-8.

40. Niraj S, Varsha S. A review on scope of immuno-modulatory drugs in Ayurveda for prevention and treatment of Covid-19. Plant Sci Today. 2020;7(3):417-23.

41. Nandan A, Tiwari S, Sharma V. Exploring alternative medicine options for the prevention or treatment of coronavirus disease 2019 (COVID-19)—a systematic scoping review. medRxiv. 2020. https://doi. org/10.1101/2020.05.14.20101352.

42. Rajput DS. Evolution, Ayurveda, immunity, and preventive aspects for emerging infectious diseases such as COVID-19. Int J Res Pharm Sci. 2020;11(SPL1):86-93.

43. Mittal B, Chand T, et al. Global care through Ayurveda in pandemic of COVID-19. Int J Health Sci Res. 2020;10(6):165-72.

44. Kar S, Gurubasavaraja B, Vikaram S, Sriharsha K, Deshpande R. Ayurvedic preventive and curative protocol for COVID 19-a proposal. J Ayurveda Integrat Med Sci. 2020;5(2):92-108.

45. Majumdar AD, Soni VM, Munjal N. Ayurveda and Yoga: An Immunity Booster at the Time of COVID-19 Pandemic. Int J Res Eng Sci Manage. 2020;3(6)

46. Kulkarni GA. Conceptual study of Aahara vidhi vishesha ayatana in pandemic disease COVID-19. J Ayurveda Integrat Med Sci. 2020;5(3):75-9. 
47. Soni H, Sharma S, Malik JK. Synergistic prophylaxis on COVID-19 by nature golden heart (Piper betle) \& Swarna Bhasma. Asian J Res Dermatol Sci. 2020;21-27.

48. Kumar V, Singh SB, Singh S. COVID-19: environment concern and impact of Indian medicinal system. J Environ Chem Eng. 2020;8(5):104144.

49. Subhrajyoti $C$, et al. Immunomodularity herbs of Ayurveda and COVID19: a review article. J Ayurveda Integrat Med Sci. 2020;5(2):203-8.

50. Rastogi S, Pandey DN. COVID-19 pandemic: A pragmatic plan for ayurveda intervention. Journal of Ayurveda and Integrative medicine. J Ayurveda Integrat Med. 2020. https://doi.org/10.1016/j. jaim.2020.04.002.

51. Panda AK, Dixit AK, Rout S, Mishra B, Purad UV, Kar S. Ayurveda practitioners consensus to develop strategies for prevention and treatment of Corona Virus Disease (COVID-19). J Ayurveda Integrat Med Sci. 2020;5(1):98-106

52. Vellingiri $B$, Jayaramayya K, lyer M, Narayanasamy A, Govindasamy V, Giridharan B, Ganesan S, Venugopal A, Venkatesan D, Ganesan H, et al. COVID-19: a promising cure for the global panic. Sci Total Environ. 2020;725:138277

53. Tillu G, Salvi S, Patwardhan B. AYUSH for COVID-19 management. J Ayurveda Integrat Med. 2020;11(2):95.

54. Gandhi AJ, Rupareliya JD, Shukla V, Dong SB, Acharya R. An ayurvedic perspective along with in silico study of the drugs for the management of Sars-Cov-2. J Ayurveda Integrat Med. 2020. https://doi.org/10.1016/j. jaim.2020.07.002.

55. Jajal R, Dive V. Probable protocol for clinical management of COVID-19 with ayurvedic treatment modalities adjuvant to ongoing conventional treatment - a review. Int J Res Ayurveda Med Sci. 2020;3:132-7.

56. Kumar A, Prasad G, Srivastav S, Gautam VK, Sharma N. A Retrospective study on efficacy and safety of Guduchi Ghan Vati for Covid-19 asymptomatic patients. medRxiv. 2020.

57. Ozah B. Triphala: a useful therapeutic supplement during COVID-19 pandemic. J Drug Deliv Ther. 2020;10(4):219-20.

58. Roy S, Bhattacharyya P. Possible role of traditional medicinal plant Neem (Azadirachta indica) for the management of COVID-19 infection. Int J Res Pharm Sci. 2020;11(SPL1):122-5.

59. Banerjee S, Srivastava S, Giri AK. Possible nutritional approach to cope with COVID-19 in Indian perspective. Adv Res J Med Clin Sci. 2020;6(06):207-19.

60. Sarika C, Nandini K, Girish T, Sharad D, Bhushan P. AYUSH, modern medicine and the Covid-19 pandemic. Indian J Med Ethics. 2020. https://doi. org/10.20529/IJME.2020.058.

61. Acharyya A. Prospect of Ayurveda system of medicine in recent COVID19 pandemic in India. Int J Ayurveda Tradit Med. 2020;2(2):26-9.

62. Berra J, Berra A, et al. COVID-19 and Ayurveda in Argentina. J Ayurveda Case Rep. 2020;3(1):41.

63. Ministry of AYUSH: Ayurveda's immunity boosting measures for self care during COVID 19 crisis. Retrieved August 11, 2020 from https://www. mohfw.gov.in/pdf/ImmunityBoostingAYUSHAdvisory.pdf.

64. Kotecha VR. Advisory From Ministry of AYUSH for Meeting the Challenge Arising Out of Spread of Corona Virus (COVID-19) in India. Secretary, Ministry of AYUSH, Government of India. Retrieved August 11, 2020 from https://www.ayush.gov.in/docs/125.pdf. 2020.

65. Government of India, Ministry of AYUSH: Guidelines for Ayurveda Practitioners for COVID 19. Retrieved August 11, 2020 from https://www. ayush.gov.in/docs/ayurved-guidlines.pdf.

66. Government of India, Ministry of AYUSH: Guidelines for Yoga Practitioners for COVID 19. Retrieved August 11, 2020 from https://www.ayush gov.in/docs/yoga-guidelines.pdf

67. Ni L, Zhou L, Zhou M, Zhao J, Wang DW. Combination of western medicine and Chinese traditional patent medicine in treating a family case of covid-19 in Wuhan. Front Med. 2020;14:210-4.

68. Wang Z, Chen X, Lu Y, Chen F, Zhang W. Clinical characteristics and therapeutic procedure for four cases with 2019 novel coronavirus pneumonia receiving combined Chinese and western medicine treatment. Biosci Trends. 2020;14:64-8.

69. Runfeng L, Yunlong $H$, Jicheng $H$, Weiqi P, Qinhai M, Yongxia S, Chufang L, Jin Z, Zhenhua J. Lianhuaqingwen exerts anti-viral and anti-inflammatory activity against novel coronavirus (sars-cov-2). Pharmacol Res. 2020;156:104761.
70. Wassenaar TM, Zou Y. 2019_nCoV/SARS-CoV-2: rapid classification of betacoronaviruses and identification of traditional Chinese medicine as potential origin of zoonotic coronaviruses. Lett Appl Microbiol. 2020;70(5):342-8

71. Jin Y-H, Cai L, Cheng Z-S, Cheng H, Deng T, Fan Y-P, Fang C, Huang D, Huang $L-Q$, Huang $Q$, et al. A rapid advice guideline for the diagnosis and treatment of 2019 novel coronavirus (2019-nCoV) infected pneumonia (standard version). Military Med Res. 2020;7(1):4.

72. Shen $K$, Yang $Y$, Wang $T$, Zhao D, Jiang $Y$, Jin $R$, Zheng $Y, X u B$, Xie Z, Lin $L$, et al. Diagnosis, treatment, and prevention of 2019 novel coronavirus infection in children: experts' consensus statement. World J Pediatr. 2020;16:223-31.

73. Yang Y, Islam MS, Wang J, Li Y, Chen X. Traditional Chinese medicine in the treatment of patients infected with 2019-new coronavirus (sarsCov-2): a review and perspective. Int J Biol Sci. 2020;16(10):1708.

74. Ni L, Yuan W, Chen L, Han C, Zhang H, Luan X, Zhao Y, Xu J, Chen H. Combating COVID-19 with integrated traditional Chinese and Western medicine in China. Acta Pharm Sin B. 2020;10:1149-62.

75. Liu M, Gao Y, Yuan Y, Yang K, Shi S, Zhang J, Tian J. Efficacy and Safety of Integrated Traditional Chinese and Western Medicine for Corona Virus Disease 2019 (COVID-19): a systematic review and meta-analysis. Pharmacol Res. 2020;158:104896.

76. Chan KW, Wong VT, Tang SCW. COVID-19: an update on the epidemiological, clinical, preventive and therapeutic evidence and guidelines of integrative Chinese-Western Medicine for the management of 2019 novel coronavirus disease. Am J Chin Med. 2020;48(03):737-62.

77. Sun C-Y, Sun Y-L, Li X-M. The role of Chinese medicine in COVID-19 pneumonia: a systematic review and meta-analysis. Am J Emerg Med. 2020;38:2153-9.

78. Fan AY, Gu S, Alemi SF, et al. Chinese herbal medicine for COVID-19: current evidence with systematic review and meta-analysis. J Integrat Med. 2020;18:385-94.

79. Tong T, Wu Y-Q, Ni W-J, Shen A-Z, Liu S. The potential insights of Traditional Chinese Medicine on treatment of COVID-19. Chin Med. 2020;15(1):1-6.

80. Huang Y-F, Bai C, He F, Xie Y, Zhou H. Review on the potential action mechanisms of Chinese medicines in treating Coronavirus Disease 2019 (COVID-19). Pharmacol Res. 2020;158:104939.

81. Xu X, Shi Y-N, Wang R-Y, Liu T, Xu J, Mao W, Sun Q-H. Home-based traditional Chinese medicine nursing interventions for discharged patients with COVID-19: a rapid review of Chinese guidelines. Integrat Med Res. 2020;9:100479

82. Ang L, Lee HW, Choi JY, Zhang J, Lee MS. Herbal medicine and pattern identification for treating COVID-19: a rapid review of guidelines. Integrat Med Res. 2020;9:100407.

83. Gray PE, Belessis Y. The use of Traditional Chinese Medicines to treat SARS-CoV-2 may cause more harm than good. Pharmacol Res. 2020;156:104776.

84. Cyranoski D. China is promoting coronavirus treatments based on unproven traditional medicines. Nature. 2020. https://doi.org/10.1038/ d41586-020-01284-x.

85. Pang B, Zhang J, Lee MS, Zheng W. Enlightenment from clinical trials on Chinese medicine for coronavirus disease 2019 (COVID-19). Integrat Med Res. 2020;9:100481.

86. Saraswati SS. Yoga Nidra. Munger: Yoga Publications Trust; 2015.

87. DSV: Spiritual Practices Recommended during Present Times. Department of Ayurveda and Holistic Health. Dev Sanskriti Vishwavidyalaya, Haridwar. Retrieved August 26, 2020 from https://sites.google.com/ dsvv.ac.in/dahh-dsvv/notices/spiritual-practices-present-times, 2020.

88. Geerlings SE, Hoepelman AIM. Immune dysfunction in patients with diabetes mellitus (DM). FEMS Immunol Med Microbiol. 1999;26(3-4):259-65.

89. Huang Y, Zhao N. Generalized anxiety disorder, depressive symptoms and sleep quality during COVID-19 outbreak in China: a web-based cross-sectional survey. Psychiatry Res. 2020;288:112954.

90. Mazza MG, De Lorenzo R, Conte C, Poletti S, Vai B, Bollettini I, Melloni EMT, Furlan R, Ciceri F, Rovere-Querini P, et al. Anxiety and depression in COVID-19 survivors: role of inflammatory and clinical predictors. Brain Behav Immun. 2020;89:594-600.

91. Rajkumar RP. COVID-19 and mental health: a review of the existing literature. J Psychiatry. 2020;52:102066. 
92. Kirkwood G, Rampes H, Tuffrey V, Richardson J, Pilkington K. Yoga for anxiety: a systematic review of the research evidence. Br J Sports Med. 2005;39(12):884-91.

93. Da Silva TL, Ravindran LN, Ravindran AV. Yoga in the treatment of mood and anxiety disorders: a review. Asian J Psychiatry. 2009;2(1):6-16.

94. Jacobs GD. Clinical applications of the relaxation response and mindbody interventions. J Alternat Complement Med. 2001;7(1):93-101.

95. Eda N, Shimizu K, Suzuki S, Tanabe Y, Lee E, Akama T. Effects of yoga exercise on salivary beta-defensin 2. Eur J Appl Physiol. 2013;113(10):2621-7.

96. Lim S-A, Cheong K-J. Regular Yoga practice improves antioxidant status, immune function, and stress hormone releases in young healthy people: a randomized, double-blind, controlled pilot study. J Alternat Complement Med. 2015;21(9):530-8.

97. Infante JR, Peran F, Rayo Jl, Serrano J, Dominguez ML, Garcia L, Duran C, Roldan A. Levels of immune cells in transcendental meditation practitioners. Int J Yoga. 2014;7:147.

98. Naoroibam R, Metri KG, Bhargav H, Nagaratna R, Nagendra H. Effect of Integrated Yoga (IY) on psychological states and CD4 counts of HIV-1 infected patients: a randomized controlled pilot study. Int J Yoga. 2016;9(1):57.

99. Rao RM, Nagendra H, Nagarathna Raghuram CV, Chandrashekara S, Gopinath K, Srinath B. Influence of yoga on mood states, distress, quality of life and immune outcomes in early stage breast cancer patients undergoing surgery. Int J Yoga. 2008;1(1):11.

100. Kusnanto N, Haryanto J, Sukartini T, Ulfiana E, Putra MM, et al. The effectiveness of spiritual emotional breathing towards respiratory function and immune response of tuberculosis patients. J Ners. 2018;13(1):93-7.

101. Tomooka LT, Murphy C, Davidson TM. Clinical study and literature review of nasal irrigation. Laryngoscope. 2000;110(7):1189-93.

102. Cohen PA, Hall L, John JN, Rapoport AB, et al. The early natural history of SARS-CoV-2 infection: clinical observations from an urban, ambulatory COVID-19 clinic. Mayo Clin Proc. 2020;95(6):1124-6 Elsevier.

103. Shi L, Wang Y, Wang Y, Duan G, Yang H. Dyspnea rather than fever is a risk factor for predicting mortality in patients with COVID-19. J Infect. 2020

104. Xie J, Covassin N, Fan Z, Singh P, Gao W, Li G, Kara T, Somers VK. Association between hypoxemia and mortality in patients with COVID-19. Mayo Clin Proc. 2020;95(6):1138-47 Elsevier.

105. Elharrar X, Trigui Y, Dols A-M, Touchon F, Martinez S, Prud'homme $E_{\text {, }}$ Papazian $\mathrm{L}$. Use of prone positioning in nonintubated patients With COVID-19 and hypoxemic acute respiratory failure. JAMA. 2020.

106. McNicholas B, Cosgrave D, Giacomini C, Brennan A, Laffey JG. Prone positioning in COVID-19 acute respiratory failure: just do it? Br J Anaesthesia. 2020.

107. Himashree G, Mohan L, Singh Y. Yoga practice improves physiological and biochemical status at high altitudes: a prospective case-control study. Altern Therap. 2016;22(5):53-9.

108. Liu X-C, Pan L, Hu Q, Dong W-P, Yan J-H, Dong L. Effects of yoga training in patients with chronic obstructive pulmonary disease: a systematic review and meta-analysis. J Thorac Dis. 2014;6(6):795.
109. Li C, Liu Y, Ji Y, Xie L, Hou Z. Efficacy of yoga training in chronic obstructive pulmonary disease patients: a systematic review and meta-analysis. Complement Therap Clin Pract. 2018;30:33-7.

110. Guleria R, Arora S, Mohan A, Kumar G, Kumar A. Yoga is as effective as standard pulmonary rehabilitation in improving dyspnea, inflammatory markers, and quality of life in patients with COPD. Chest. 2015:148(4):907.

111. Fulambarker A, Farooki B, Kheir F, Copur AS, Srinivasan L, Schultz S. Effect of Yoga in chronic obstructive pulmonary disease. Am J Therap. 2012;19(2):96-100.

112. Donesky-Cuenco D, Nguyen HQ, Paul S, Carrieri-Kohlman V. Yoga therapy decreases dyspnea-related distress and improves functional performance in people with chronic obstructive pulmonary disease: a pilot study. J Alternat Complement Med. 2009;15(3):225-34.

113. Ranjita R, Hankey A, Nagendra H, Mohanty S. Yoga-based pulmonary rehabilitation for the management of dyspnea in coal miners with chronic obstructive pulmonary disease: a randomized controlled trial. J Ayurveda Integrat Med. 2016;7(3):158-66.

114. Gupta A, Gupta R, Sood S, Arkham M. Pranayam for treatment of chronic obstructive pulmonary disease: results from a randomized, controlled trial. Integrat Med Clin J. 2014;13(1):26.

115. Nagendra H. Yoga for COVID-19. Int J Yoga. 2020;13(2):87.

116. Bushell W, Castle R, Williams MA, Brouwer KC, Tanzi RE, Chopra D, Mills PJ. Meditation and yoga practices as potential adjunctive treatment of SARS-CoV-2 infection and COVID-19: a brief overview of key subjects. J Alternat Complement Med. 2020;26(7):547-56.

117. Central Council of Indian Medicine: Telemedicine Practice Guidelines for Ayurveda, Siddha and Unani Practitioners. Retrieved September 12, 2020 from https://www.ayush.gov.in/docs/CCIM_Telemedicine_Guide lines.pdf. 2020.

118. Government of India, Ministry of AYUSH: Notification from the Ministry of AYUSH for undertaking research on Covid 19 through Ayurveda, Unani, Siddha and Homeopathy systems. Retrieved September 12 2020 from https://www.ayush.gov.in/docs/127.pdf. 2020.

119. Sandu Pharmaceuticals Ltd.: Pathyadi Kadha. Retrieved August 8, 2020 from http://www.sandu.in/pathyadi.html.

120. Himalaya: Diabecon. Retrieved August 8, 2020 from https://himalayawe Ilness.in/products/diabecon.

121. Sharma PV. Dravyaguna Vijnana, Volume II (vegetable Drugs) (Hindi). Chaukhambha Bharati Academy, Varanasi, Uttar Pradesh, India, 2001.

122. Jha CB. Ayurvediya Rasashastra. Chaukhambha Surabharati Prakashan: Varanasi, India; 2000;325.

123. Dr. H R Nagendra DRN. New Perspectives In Stress Management. Swami Vivekananda Yoga Prakashana, Bangalore, India. 1986.

\section{Publisher's Note}

Springer Nature remains neutral with regard to jurisdictional claims in published maps and institutional affiliations.

Ready to submit your research? Choose BMC and benefit from

- fast, convenient online submission

- thorough peer review by experienced researchers in your field

- rapid publication on acceptance

- support for research data, including large and complex data types

- gold Open Access which fosters wider collaboration and increased citations

- maximum visibility for your research: over 100M website views per year

At $B M C$, research is always in progress.

Learn more biomedcentral.com/submissions 